\title{
An Analysis of a Local and International University-Graduated Teachers Questioning in English for Specific Purposes Class
}

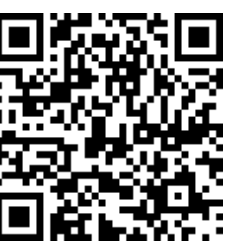

\section{Alsuna: Journal of Arabic and English Language}

Irene Rosalina
Universitas Negeri Surabaya
irene.17070835033@mhs.unesa.ac.id
Slamet Setiawan
Universitas Negeri Surabaya
slametsetiawan@unesa.ac.id
Suhartono
Universitas Negeri Surabaya
suhartono@unesa.ac.id

Keywords:

Questioning

Communicative

Critical Thinking

Article Information:

Submitted: April 17, 2020

Accepted: April 20, 2020

Approved: May 27, 2020

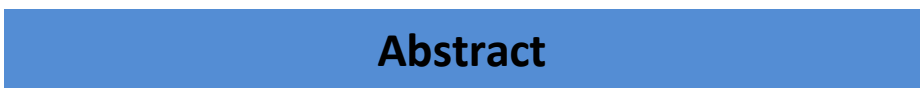

Purpose - The study investigated the display and referential questions used by the local and International educated background teacher in English for Specific Purposes classroom to promote communicative English class.

Design/methodology/approach - The study was qualitatively held, to find out the answer to the research questions, classroom observations, and interviews with two teachers were conducted.

Findings - The results indicated that both of the teachers asked higher-order questions in referential type more frequently than teachers in other studies and it could trigger communication effectively. the teachers delivered the questions within their styles. The local educated teacher used mixed IndonesianJavanese and English to help the students understood the questions and respond well, but the internationally educated teacher employs the questions into whole English. She probes the questions a lot of time to make the questions understandable and simpler. The wait time given was much longer. Some analysis questions were composed to gain the student's braveness to express their answer.

Originality/value - This study offered recommendations for effective teachers' questioning types and techniques for the development of learners' communicative skills, especially in an ESP class.

Paper type - Research paper

\section{Introduction}

A teacher is expected to not only teaching the students about the material to achieve the goals of the study but also be the guide enabling the students' process of language learning and language mastery in class. Moreover, in a classroom of language were the students supposed to be performed well communicatively, teachers have to assist them to practice the language actively especially if the students are known for not coming from the language learner's background of studies, such as engineering, management, and mathematics 
department students where they should learn English especially in their English for specific purpose class to support the fact that students from another background of study have to master English well to compete for globalization (Sholah 2019). Having English competent is a demand for the forthcoming future and to be able to have communicative English competence means that the students have to understand and prompt the information, thinking, and minds (Aziz and Dewi 2019).

Also, to produce communication, the teacher's questioning is called to be the most used in the class. It is in correlation with Nunn (1999) and Ho (2005) that about the promotion of communicative language teaching and focus on students' need of being able to communicate, they said that the study of the language classroom, especially about teachers' discourse, has mostly intense on teachers' questions (Nunn 1999).

Teacher questions are essential in the teaching and learning process of language, and the questions can be used as the teaching quality indicators (Freiberg et al. 2016). King (1994) said that "The critical thinking and depth analysis of students can be built through some stimulation from some good questions(King, Goodson, and Rohani 1988). Several studies investigating teacher questioning have been carried out by some researchers. Shen (2017) compared that between native speaker and non-native speaker teachers' questioning as well as the effects of teacher questions on students' verbal production he found that if native speaker English teachers are truthfully effective in English teaching and the teaching mode (Native speaker (NS)/ Non-native speaker (NNS) team-teaching) give good contribution to students' verbal communication. Furthermore, it can be concluded that display questions in both of NS and NNS teachers' stimulated brief and little answers while referential questions elicit students to make longer and syntactically more complex utterances(Shen and Yodkhumlue 2012). Another study by Shomoossi (2004) observed the use of display and referential questions and focusing on the effects of asking referential questions on communication among students. The result exhibited that teachers used to display questions 4.4 times more regularly than referential questions, however, it was also found that, most, and referential questions produce more communication than display questions, particularly in higher-level students of language class (Shomoossi 2004). Another study was done by David (2007) exploring the distribution difference between the teachers' use of display and referential questions as well as the effects of teachers' questioning on ESL classroom interaction showed that the display questions used by the language teacher are better than 
the referential questions. Moreover, he concluded that display questions produce more chance for the exchanges of teacher and student in English classrooms although the involvement of the student is minimal (12.4 \%) (Nunan 2005).

So far, however, there has been little discussion about the teacher's questioning usage

in English for a specific purpose class with a local graduated University (Indonesia) teacher and an International graduated University teacher. The teacher is a prominent aspect of language teaching in class. He or she could be the real live input and the role model of the language practice. Since many years ago, English teaching in class mostly believed that having a native speaker of English from the English speaking country means that the teaching and learning process would be better than having the non-native teacher in class (Mariño 2011).

There is a big dichotomy between native and non- native teachers. Marino (2011) even compares that the native speaker is good because of some reasons. They acquire the first language of which she or he is a native speaker of English in childhood. The native speaker has intuitions (in terms of acceptability and productiveness) about his or her grammar, then the native speaker has a unique capacity to produce fluent spontaneous discourse, which is facilitated by a huge memory stock of partly or completely lexical units. The native speaker has a unique creative capacity that enables him or her to write or speak creatively. Speaking creatively probably belongs here too as does linguistic creativity and originality (Road and Province 2018). Native speakers are not the only model English learners may follow; of course, they have acquired the language and hence, they are supposed to speak it properly; but it is also true, that talking a language, does not mean managing it to a whole extent (Sköldvall 2015).

As it is well known, spelling and grammar are some of the weak areas of native speakers; while foreign-language speakers are taught, basically, in terms of the grammar and the right writing of a language (Rizki 2018). This is the way we "understand" their language, whereas they just "hold" and "use" it without knowing the special features of its language. Non-native speakers have different uses of second languages than native-monolingual if it is true that non-native speakers may have certain abilities and advantages due to the fact they are managing two languages, how are these skills taken into account in the field of language teaching (Ziad hadla 2013). Non-native speakers may have greater abilities when teaching students a second language because they can teach learning strategies more effectively, provide learners with more information about the second language, anticipate students' needs 
and difficulties when learning the second language, be more concerned to the needs and problems of their students, share the students' mother tongue when necessary and to achieve a greater experience and understanding when teaching-learning the language (Trim 1992). As mastering English include in the curriculum of Indonesia, some teachers study English as their choice of program in their University study. In studying English, some of the teachers' study English in a domestic University and in an International University abroad, that then they also called as the non-native English teacher in class.

Studying at a domestic or local University means that the teacher learns and acquires English within their own country, here in Indonesia. The domestic educated teacher is educated with the educational system in Indonesia. The curriculum of the higher education they got must be based on the ministry of education in Indonesia. They graduated from the English department after they accomplished some courses. From the education situation, they mostly engaged with the same cultural surrounding. But then, there are numbers of Indonesian teachers choosing to study abroad international higher education universities. And it has increased by more than eight percent in the past year, especially in Australia. Australia has been the study destination of choice for Indonesians for the past ten years, with one in four students who study at university overseas choosing Australia. Australian Ambassador to Indonesia said the greater flows of Indonesians to Australia were the result of a continuing strategy to increase Indonesian student enrolments at Australian universities.

In studying internationally, they experience "life-changing," "turning point," "experience of a lifetime," "eye-opening," and "horizon-broadening."(Paul and Elder 2013). Stilianos et al. (2013) stated that because of the international study, students can gain experience in different educational systems and be involved in other learning processes. The students can gain critical thinking and the communicative situation in other educational systems. Besides, the students would experience multiculturalism and intercultural education. Studying abroad means that they get worldviews and it creates globally-minded students"(Wright 2016). The foreign country study abroad, especially for students studying a foreign language, is clearly seen as the best path towards a higher level of intellectual and cognitive development. It is a unique and novel experience that heightens students' perceptions of the world they live in, as well as a unique chance to utilize each students' critical thinking skills and improve them (Mozeleski 2013). McKeown (2011) in Miller (2014) mentioned the statement that the change in behaviour. The support for that statement comes 
from research further mentioned related to cultural and linguistic input that is separate from the students' home culture and language when an individual experiences another culture, they are changing the input that helps them form cognitive and intellectual schemas about the world and how it works (Mozeleski 2013). It would require that a person be interacting regularly with an environment, and it could also be inferred that those who have different environments may be at different stages of development. It may also be inferred that if one changes one's environment, and thus the impact, then one would see a different impact from the environment compared with those who did not change their environments (Hui 2015).

\section{Methodology}

A qualitative study used here in order to effectively provide a general and satisfactory description of the teachers' questioning used by both teachers. The qualitative research design conducted to make the findings be presented in open-ended, non-numerical data analysed through non-statistical methods.

Two teachers which each of them is from Local (Indonesian) University graduated teacher and International (Australian) University graduate teacher were included in this study. The intention of selecting them is to get a picture of how they use the questioning in the class from the side of local University graduation and abroad University graduation which likely engaged more with the native speaker. Besides, the students of an ESP class joined in this study because it can be clearly seen that they join the ESP class in order to master the communication in English that is why we need to see how the teacher elicits their communication skills by stimulating them through teachers' questioning.

Furthermore, data triangulation implemented to avoid the bias of the study. Class observation, Teachers interview, and student's questionnaire will be done in this study to get deeper data needed in the study. Then the data collected were coded by using the display and referential codebook and will be described in open-ended findings. The collection of raw data includes 5 times sections of classroom observations in which each observation lasted for 90 minutes, 60 minutes teacher interview, and the students' questionnaire. The audio-taped data during the teaching and learning process observation are transcribed verbatim individually by the researcher and used as the major source for data analysis. In addition, the audio-taped data was transcribed by using the transcription conventions adapted from Tseng (1992) in Rohmah (2017) for classroom discourse (Taufiqur Rohmah 2017). 
The coding of teacher questioning from the observation and interview are critical exchanges of introduction in the process of Initiation-Response-Follow-up (IRF), whereas the function of the initiation move is to generate the chance for others to partake in the exchange. By having initiating questions, the teacher leads and controls the entire class. Moreover, the challenge for the teachers of language is how to provide students with more opportunities to talk and how to provoke more language production from the students.

Furthermore, the coding of teacher question types in the study is adopted from Verplaetse (1995) in Enoising (2006) as seen below:

"U: Referential questions (a question where the answer is on the open-ended answer) are coded " $\mathrm{U}$ "”.

“K: Display questions (a question where the answer is already known by the teacher) are coded "K"'" (Enoising 2012)

The data gained from the teachers' questions during the teaching and learning process. It was analysed through some steps to capture the expression used by the teachers in employing questions in the classroom. Generally, Miles et al. (2014) classify data analysis into three concurrent flows of activity, such as: data reduction, data display, and conclusion drawing or verification (Miles and Huberman 2014).

In data reduction, the data is selected from the words, phrases, or sentences of the English teachers' questions in class. The data will be grouped into a display and referential questions made by the teachers and compiled deeply into the questions which can direct to develop the critical thinking of the students and found out the way how the teachers employ the questions.

Then, in transcribing the data, the researcher used coding for selecting, categorizing, and simplifying the transcription, and the coding system is adopted from Allwright and Bailey (1991).

\begin{tabular}{|c|c|}
\hline CODE & EXPLANATION \\
\hline $\mathbf{T}$ & Teacher \\
\hline S1 & Student using numbers $(\mathrm{S} 1, \mathrm{~S} 2, \mathrm{~S} 3)$ \\
\hline SS & Unidentified sub group speaking in chorus \\
\hline T+SS & Teacher and an unidentified subgroup of students \\
\hline SSS & Whole class speaking in chorus \\
\hline T+SSS & Teacher and whole class \\
\hline (...S) & Pause Length in second \\
\hline
\end{tabular}




\begin{tabular}{|l|l|}
\hline (.) & Very short untimed pause \\
\hline [ ] & Comment \\
\hline XXX & Incomprehensible item \\
\hline I/ & Pauses \\
\hline Italics & Bahasa Indonesia \\
\hline DSP & Display question \\
\hline RF & Referential question \\
\hline CT & Critical thinking enforcement \\
\hline KNW & Factual Knowledge \\
\hline INT & Interpretation \\
\hline AN & Analysis \\
\hline EV & Evaluation \\
\hline INF & Inference \\
\hline EXP & Explanation \\
\hline SLF & self- regulation \\
\hline Table 1: Data Transcription Code (Modified from Allwright \& Bailey
\end{tabular}

Table 1: Data Transcription Code (Modified from Allwright \& Bailey

To get the authenticity of the data, the observations were done the minimum to get the real condition of the teachers' questioning and the response of the students. Data triangulation was implemented to validate and strengthen the data findings by cross verifying the information.

This study was done based on some limitations such as the questioning will be classified based on the theory of Walsh that teacher questioning is divided into two types, display, and referential questioning. The participants of the study were chosen from the teacher graduated from local and International University who got a scholarship in their previous study.

\section{State of The Arts and Distinguish}

This study is proposed to be done to see the teacher's questioning by the local graduated university and abroad graduated university teacher in ESP class since that the research toward non-native English teachers who achieved local and International education background has not been investigated thoroughly related with the questioning in class. As we could see from the previous researches above mostly the research was done emphasizing on the native and non-native speakers, the big dichotomy distinguish was based on those two considerations without considering the fact that there were also non-native speakers who 
experienced in studying English abroad, who develop their speaking, their teaching and their way of life in English speaking country. We know that the trends of English for a specific purpose has been raised in a University within the different background of students inside who like to learn English well to support their future career, and the heterogeneous background of teachers, in term of Indonesian graduated or Abroad graduated are also commonly seen to teach them, but then a study to see how they help the students and eliciting the communication in rarely being investigated.

However, most of the teachers ask questions and use the type of questions in class to request more open, realistic, and factual information rather than only student reasoning (Debora Tri Ragawanti 2009). The type of questions that fit that criteria are the type of teacher's questions proposed by Walsh (2011) where it will be the grand theory in framing this study. He said that there are two types of teacher questioning, "display and referential" question (Walsh 2011a). Walsh (2011) said that "Essentially, the defining characteristic of display questions is to check or evaluate: understanding, concepts, learning, previous learning, and so on. Responses tend to be short, simple, restricted, often comprising one or two words. Apart from display questions, teachers also ask genuine, more open-ended questions, designed to promote discussion and debate, engage learners and produce longer, more complex responses, these so-called "referential questions". Then this study focused to answer the research questions as 1) How do display and referential questions used by local and International graduated university teachers in ESP class? 2) what does the effect of teacher's questioning usage toward the student's communicative development in the ESP class?

\section{Result and Discussion}

The classroom observations in the local educated teacher were done in the ESP class. The material of the lesson was about simple sentences and experience. The concept of the simple sentence and experience were given previously to the class, while the class observation was employed mostly on the application and presentation of the subject matter. The questionanswer process occurred in that circumstance. Meanwhile, the classroom observation with the internationally educated teacher was done in ESP class as well. The material of that day was quite challenging, they were introduced to material of different cultures to stimulate their interest in speaking in English. The first observation was the introduction of English-speaking country culture and the second observation was about the difference in shopping abroad. For 
the first meeting, the teacher played a videotaped of social life in Australia. The video showed the atmosphere in Australia and some students from different backgrounds share their experience of living and studies abroad and in the second observation, the students were given an audio playing of a shopping situation abroad. The main discussion and questioning of the teaching and learning process were done mostly after the recording played by the teacher.

The usage of display and referential questions by both of the teachers serve some purpose in triggering communication in English. It was found out that the intention of asking the display question in the class was to elicit a response, check the understanding, guide learners towards a particular response, and recall information, meanwhile, the referential question aims to elicit a longer response, stimulate discussion and encourage conversation. The questions which promote communication could be made from these two kinds of question, regarding the purpose. For the detail, it can be seen from the table below:

\begin{tabular}{|c|c|c|c|c|}
\hline NO & TYPES & PURPOSES & LOCAL & INTERNATIONAL \\
\hline \multirow[t]{4}{*}{1} & \multirow[t]{4}{*}{ Display } & Eliciting response & 19 & 18 \\
\hline & & Checking to understand & 12 & 10 \\
\hline & & $\begin{array}{l}\text { Guide Learner toward a particular } \\
\text { response }\end{array}$ & 9 & 2 \\
\hline & & Recall information & 6 & 3 \\
\hline \multirow[t]{3}{*}{2} & \multirow[t]{3}{*}{ Referential } & Eliciting longer response & 5 & 4 \\
\hline & & Stimulate discussion & 54 & 44 \\
\hline & & Encourage discussion & 3 & 2 \\
\hline
\end{tabular}

Table 2: The Distributions on questioning based on the Purposes

From the table above, it can be inferred that questions made by both of the teachers, whether it was a display or referential questions, served some range of purposes in the course and used in different coincidental in class. The display questions expected to elicit a response, check to understand, guide learners toward particular response, and recall information. Then the referential question intended to elicit a longer response, stimulate discussion, and encourage discussion. In general, there were a lot of questions applied by the teachers during classroom activities. There were about 191 questions used by both of the teachers in the meetings.

Additionally, during the teaching and learning process, the local educated teacher used English and Indonesian and sometimes mixed between. In relation to the students' native language, teachers sometimes employ native language in doing classroom talks as well as 
questioning that can help or support students in understanding the material. It was quite different from what the internationally educated teacher where she led into a fully English class. She used English all the time without any mixed language. She listened to the students' answers in Indonesia but then direct them to try to answer in English. The display and referential questions brought by the teachers performed as initial and follow-up questions. There were questions brought up firstly and then followed by other questions to get a deeper understanding and to reach the objective of the class.

Display questions are the ones whose answers are already known to the teachers. It means those questions for which the teacher has already known the answers, the exactly right answer, before delivering the questions, and requires students to display information and the knowledge. The display questions ask for factual knowledge.

Furthermore, as portrayed from table 2, the purpose of asking the question was mainly characterized to serve display and referential classification. The total display question usage in class was not slightly different, 46 times for local educated teachers, and 33 times for internationally educated teachers during the teaching and learning process. The display questions made by both of the teachers were directed to gain the answer that been known by the teachers. The display questions performed mostly at the beginning of the discussion or at the starting point of the lessons. In eliciting the response, guide learner toward an answer, checking to understand and recall the information, the characteristic of the display questions were exposed to let the students captivate the knowledge so it deeply created to indicate factual answer, checking. Another type of question beside the display question was a referential question. The referential question referred to a question which the response was not known by the teacher, which means that the response could be genuinely from what the students think about what they had discussed, but still be related to a subject matter (Walsh 2011a). The referential question was not asked about factual knowledge, it let the students broaden and sharpen their critical thinking through their analysis, explanation reflected in their communication

Just like display question, referential question serves some purposes in the ESP class. The referential question made was delivered deeply to stimulate students' communication skills. The referential questions basically triggered the students to produced longer responses and let them answer within the answer that was not already known by the teacher, so the answer can be honestly made by the students. Referential questions were indeed to elicit a 
longer response, to stimulate discussion, and to encourage conversation concept and recognition of the information.

As it was previously found that in this study showed that both of the local and internationally educated teachers used some questions in ESP class, categorized in display and referential questions, to serve some aims toward the students. While display questions are the ones whose answers are already known to the teachers, referential questions' answers are not known and they are completely based on the respondents' knowledge (Brock 1986). Ellis (1994) discriminates these two types as open and closed questions. While display questions are likely to be closed, referential ones are more likely to be open questions. The finding is inconsistent with the literature review that the usage of display questions are to elicit a longer response, checking to understand, recall information, guiding toward particular response and referential questions are to elicit a longer response, stimulate discussion, encourage conversation (Walsh 2011b). Eliciting response purpose questions were implemented several times more than other purposes in order to let the students interact and precede their oral practice although the response of the students was just in short. The students were just answering in yes or no for questions and even a single word such as in question showed that this condition was in line with Nunan (2005) as he mentioned that display questions elicit "short, mechanical responses", it is different with open or referential questions that can cause "lengthy, often complex responses" (Nunan 2005).

What was different from the findings in the previous section was that in this study, both of the teachers, as the non-native English speaker, who differed from the educational background, local and international educated, could contribute more referential questions in the classroom. This contradicted the findings of most teachers as the non-native teachers, as mentioned in (Road and Province 2018), which preferred to use display questions in class. The referential questions made by both teachers outnumbered the display questions. From the interview, they mentioned that they realized the importance of having discussions to promote communication. The interesting things happened in the questions in the class made by the internationally educated teacher were delivered in such a way and added with some analogies if the students could not understand the questions or needed to think, she added the stories of her experiences, she shared her information that motivated the students to be engaged within the lesson and eager to try to answer the questions. The internationally educated teacher has used full English teaching. Whether her classroom talk and especially classroom 
questioning was entirely in English. Phillipson (1996) in Soyadi (2014)concerns non-native speaker teachers of English as 'ideal' language teachers ever since they obtain English as an additional language; they have the first-hand experience in learning and using language as a second language, thus this experience prepares them to the linguistic and cultural needs of their students (Yazar Soyadı 2015). Mahu (1992) also supports the same idea and claims that non-native speakers have more recompenses when the role of the instructor is important because they have experience as second language learners of English and this experience makes them aware of the target language (Mahu 2012). Therefore, the feature of having experience in the language learning process contributes to the teaching skills of non-native speaker teachers a great deal. Furthermore, non-native speaker teachers can be better in specific areas since they have a fortuitous to benefit from sharing the learners' mother tongue in monolingual classes.

In the findings, the display questions made by the local educated teacher took a greater number in class than the internally educated teacher. It assisted the students to check their understanding, and recall information than the internationally educated teacher was because the local educated teacher had already discussed the theory of the subject matter in the previous meeting and in the day of observation was only concentrate to ask the students to show the application of the theory given, those were simple sentence and past experience on the second meeting. It was different from what the internationally educated teacher did in the observation that the class she taught was right away talking about the subject matter and the discussion section as well. Knowledge and comprehension aspects were also gained in this display question implementation especially in the process of checking understanding and recall information as shown in the findings of Omari (2018) indicated that display questions were on low thinking level (Omari 2018). The results of other studies suggest that responses to questions calling for the recognition or recall of factual information are shorter than responses to higher-order questions calling for interpretation or opinion (Roostini 2011).

However, the questions made by both of the teachers had made up the referential types and served some purposes of this type as well. Some responses showed that by giving referential questions, students could reach longer responses, and actually it represented other purposes like discussion stimulating included some critical thinking aspects within. In stimulating discussion, there is some critical thinking aspect that was promoted by the teachers such as interpretation, analysis, evaluation, inference, explanation, and self-regulation. 
In interpretation questions, the teachers tried to stimulate the capability of the students to express the meaning behind the information they got from the material of the classroom discussion, while in analysis questions the teachers tended to trigger the ability to identify the intended and actual relationships among statements, questions, concepts, descriptions, or other forms of representation intended to express belief, judgment, experiences, reasons, information, or opinions. In evaluation, assess the credibility of statements or other representations which are accounts or descriptions of a person's perception. Inference means "to identify and secure elements needed to draw reasonable conclusions; to form conjectures and hypotheses. Explanation as being able to present in a convincing and comprehensible way the results of one's reasoning. This means to be able to give someone a full look at the big picture: both "to state and to justify that reasoning in terms of the evidential, conceptual, and contextual considerations upon which one's results were based; and to present one's reasoning in the form logical arguments. In the self-regulation aspect, the teachers motivated the students to self-consciously monitor their cognitive activities, the elements used in those activities, and the results extracted, particularly by applying skills in analysis, and evaluation to one's own inferential judgments with a view toward questioning, confirming, validating, or correcting either one's reasoning or one's results.

Having been exposed to a number of referential questions to which students responded with their own opinions, their responses when facing challenging questions enhanced. This supported what Nunan (2005) stated that referential questions that can cause "lengthy, often complex responses" (Nunan 2005). This was because both of the teachers bared them with many referential questions, especially on giving them the opportunity to have a discussion through their complex questions. The students started to share their own ideas and come up with different opinions when faced with referential questions, their responses were triggered through some questions in the form of interpretation, analysis, inference, and explanation and self-regulation matter.

The local educated teacher was found to deliver some of the questions triggering the self-regulation aspect of critical thinking many times, this helps students comprehend then communicate well. In the evaluation section of her class, she exposed self-regulation questions. Meanwhile, from the internationally educated teacher, the questions made were mostly on referential questions for stimulating discussion and in the form of analysis questions related to the critical thinking promotion. 
The analysis showed that referential questions facilitated more student participation and communication than display questions. Referential questions require students to provide genuine information that neither the teacher nor other students in the class may have. It was found that referential questions elevated student participation particularly when the students were provided with amounts of language to do the task when necessary and given enough time to consider the question and their responses. Generally, most responses appropriately, the ideas, and is quite clear and can be understood. The results also reveal that referential questions are underemphasized by the teachers, although these questions elicit longer and more authentic responses than display questions do. Referential questions encompass the exchange of information and cooperation of meaning among all class participants, which could help teachers get the necessary feedback for eliciting more information from students (Nunan 2005).

With regard to the usefulness of teachers' questions, participants responded positively. As to teacher interviews, the local educated teacher viewed questioning as an effective tool for developing learners' communication skills. An internationally educated teacher also considered questioning as an effective means for enhancing learners' communication skills, but the teacher viewed such an advantage of asking questions was limited to those who actively participate in question-answer interactions. This is what the expert stated that asking questions can be a means through which communication and critical thinking skills can be developed (Seker and Kömür 2008).

In giving the questions, each of the teachers has their own way. The result of the videotaped transcription reveals that while teaching the local educated teacher sometimes mixed her language between Indonesian English and Javanese, and she used Indonesian and Javanese questions for instance She mixed her language in order to make the students easier to understand the questions. The mixing language she used occurred many times in the classroom means that she wants to elevate the knowledge through language that is familiar to the students in order to avoid misunderstanding and easier reception.

\section{Conclusion}

This study investigated display and referential questioning and gave an exact explanation on the way the local and internationally educated teacher delivering questions in ESP class to promote English communication. Data on questions-response interactions, the 
analysis of the intention of giving questions, the classifications of the function of questioning related to critical thinking stimulating, and the techniques used by both of the teachers were collected based on the classroom observation and interview from both of the teachers. All the data gained in this study was treated qualitatively. Based on the data gained through the observation, the questions made by the teacher were classified into types as Walsh (2011) mentioned, display and referential questions (Walsh 2011a). The result showed that the questions made by both of the teachers indicated the response elicitation, understanding checking, information recalling, discussion stimulation, conversational encouragement, and longer response triggering. The result also indicated that both teachers asked higher-order questions relatively more frequently in referential type of question in especially in stimulating discussion regarding lead them to analyze some subject matters and stimulate their communication as well as developing comprehension that could lead to critical thinking empowerment.

\section{Implications of Findings}

This study offers recommendations for types of questions and effective teaching techniques for the development of the communicative skills of students, especially in English for Specific Purposes class. Then in the pause between asking questions and waiting for the results of students' answers, the teacher should not be too hasty. It is a good time to wait for an answer between 5 to 10 seconds, to allow students to think critically and the teacher realizes that this is not talking to students, not-native speak.

\section{Bibliography}

Aziz, Imam Nur, and Yuli Ani Setyo Dewi. 2019. "The Implementation of Contextual Teaching and Learning on English Grammar Competence." ALSUNA: JOURNAL OF ARABIC AND ENGLISH LANGUAGE. https://doi.org/10.31538/alsuna.v2i2.392.

Brock, Cynthia a. 1986. "The Effects of Referential Questions on ESL Classroom Discourse." TESOL Quarterly 20 (1): 47.

Debora Tri Ragawanti. 2009. "Questions and Questioning Techniques: A View of Indonesian Students' Preferences." K@Ta 11 (2): 155-70. https://doi.org/10.9744/kata.11.2.155170.

Enoising, D. 2012. “I Mage S Egmentation and T Otal V Ariation,” no. 1995: 1-12. 
Freiberg, H Jerome, William S Carlsen, Kennedy Hall, William S Carlsen, and Kennedy Hall. 2016. “Never Ask A Question If You Don ' $t$ Know the Answer: The Tension in Teaching Between Modeling Scientific Argument and Maintaining Law and Order Never Ask A Question If You Don ' $t$ Know the Answer: The Tension in Teaching Between Modeling Scientific Argu."

Hui, Lansing. 2015. "Intercultural Communicative Competence, Language Proficiency, and Study Abroad" 4 (2): 57-67.

King, F J, L Goodson, and F Rohani. 1988. "Higher Order Thinking Skills: Definition, Teaching Strategies, Assessment." Center for Advancement of Learning and Assessment.

Mahu, Diana-Petruţa. 2012. "Why Is Learning English So Beneficial Nowadays?” International Journal of Communication Research 2 (4): 374-76.

Mariño, Claudia. 2011. "Reflecting on the Dichotomy Native-Non Native Speakers in an EFL Context" 10: 129-41.

Miles, B. Matthew, and A. Michael Huberman. 2014. Qualitative Data Analysis. London: Sage Pubiications.

Mozeleski, Mariśca D Martin. 2013. "The Cognitive and Linguistic Benefits of Study Abroad for All Students." Murray State's Digital Commons, 27.

Nunan, David. 2005. “Languag Teaching Methodology.” New York: Prentice Hall.

Nunn, Roger. 1999. "The Purposes of Language Teachers' Questions." IRAL - International Review of Applied Linguistics in Language Teaching 37 (1): 23-42.

Omari, Hamzah A. 2018. "Analysis of the Types of Classroom Questions Which Jordanian English Language Teachers Ask." Modern Applied Science 12 (4): 1.

Paul, Richard, and Linda Elder. 2013. "Critical Thinking Competency Standarts," 1-6.

Rizki, Dini. 2018. "Native vs. Non-Native EFL Teachers : Who Are Better ? 1" 5 (September 2017): 137-47.

Road, Dianzi, and Shaanxi Province. 2018. "A Case Study of NS and NNS English Teachers Classroom Discourse in an EFL Setting" 113 (Sshr 2017): 322-28.

Roostini, Kasih Elisabeth. 2011. "A Reflection on Teacher Questioning Types." Indonesian Journal of Applied Linguistics 1 (1): 10.

Seker, Hasan, and Şevki Kömür. 2008. "The Relationship between Critical Thinking Skills and In-Class Questioning Behaviours of English Language Teaching Students." European $\begin{array}{llllll}\text { Journal of } & \text { Teacher } & \text { Education } & 31 & \text { 389-402. }\end{array}$ 
https://doi.org/10.1080/02619760802420784.

Shen, Ping, and Butsakorn Yodkhumlue. 2012. "A Case Study of Teacher's Questioning and Students' Critical Thinking in College EFL Reading Classroom." International Journal of English Linguistics 2 (1): 199-206.

Sholah, Hanif Maulaniam. 2019. "Enhancing EFL Learners' Writing Skill via Journal Writing." ALSUNA: JOURNAL OF ARABIC AND ENGLISH LANGUAGE. https://doi.org/10.31538/alsuna.v2i2.397.

Shomoossi, Nematullah. 2004. "The Effects of Teachers' Questioning Behaviour on EFL Classroom Interaction: A Classroom Reseacrh Study." The Reading Matrix 4 (2): 96-104. Sköldvall, Henning. 2015. "Non-Native Speaker Interaction Non-Native Speaker Interaction." Taufiqur Rohmah, Ima Isnaini i. 2017. "Classroom Interaction in English Language Class for Students of Economics Education." Ssrn $8 \quad$ (2): 192-207. https://doi.org/10.2139/ssrn.3005587.

Trim, John. 1992. "Who ' s Worth More ? Péter Medgyes" 46 (October): 340-49.

Walsh, Steve. 2011a. "Exploring Classroom Discourse."

- - . 2011b. Steve Walsh Exploring Classroom Discourse Language in Action Routledge Introductions to Applied Linguistics 2011. London: Routledge.

Wright, Brenda M. 2016. "Display and Referential Questions: Effects on Student Responses." NJES Nordic Journal of English Studies 15 (4): 160-89.

Yazar Soyadı, Bengi Birgili. 2015. "Creative and Critical Thinking Skills in Problem-Based Learning Environments." Journal of Gifted Education and Creativity 2 (2): 71-71. https://doi.org/10.18200/JGEDC.2015214253.

Ziad hadla. 2013. “Perceptions, Teacher Speaking, Non-Native English,” 1-291. 